\title{
Influence of physical culture innovative means on functional state of second maturity women
}

\author{
Konakova O.Y. \\ Dnipropetrovsk State Institute of Physical Culture and Sport
}

\begin{abstract}
Purpose:

to find influence of physical culture innovative means (combination of "Pilates" - exercises for body and mind - and program "Port de bras" (movements of arms and body)) on functional state of second maturity women.

Material: $\quad 22$ women of age from 50 to 55 were tested; they were divided into main and control groups. Control group practiced health related swimming; experimental group was trained by system "Pilates" and program "Port de bras" with application of special equipment.

Results: $\quad$ it was found, that for confident changes in women's functional systems it was necessary to practice trainings in zone of sub-maximal load (75-85\% from maximal oxygen consumption); trainings in zone of low intensity do not give confident health related effect.

Conclusions: At low and below average women's physical fitness it is necessary to practice health related trainings in zone of low intensity (mean heart beats rate $-90-115$ beats per minute). For increasing trainings intensity it is necessary to raise women's physical fitness.

Keywords: functional state, Pilates, Port de bras, women, maturity
\end{abstract}

\section{Introduction}

Physical culture plays important role in women's health improvement, in prevention from too early ageing and maintaining women's high workability during all life span $[3,6,10]$. Traditional physical education means can not completely ensure high effectiveness of health improvement process for different population strata [2022]. It forces physical culture establishments to implement innovative physical culture means in trainings. They imply combining of already existing fitness programs of different orientation. In this connection researches, directed at scientific substantiation of health related fitness for different population categories, become still more relevant $[7,8,10,17]$.

Specialists determined positive influence of health related fitness of physical condition of second maturity women:

- "Pilates" (complex of physical exercises, invented by German sportsman Joseph Pilates at the beginning of $20^{\text {th }}$ century, is a combination of Yoga, ballet, and isometric exercises and permits to improve external breathing functioning (lungs' ventilation function) in 36-55 years' age women [1];

- "shaping" - a kind of rhythmic gymnastic, directed at changing of body shape. It effectively influenced on morphological functional indicators of this age women. Scientific data witness about confident reduction of body mass, fat percentage in organism, waist, thigh and arm circumferences. Blood pressure, heart beats rate in relaxed state significantly reduced. It positively influenced on women's cardio-vascular system [15];

- athletic gymnastic effectively influenced on anthropometrical and functional indicators of 35-45 years age women. It reflected in reduction of body mass, subcutaneous fat indicators. Vital capacity of lungs confidently increased. Besides, heart beats rate indicators and blood pressure in relaxed state reduced [13];

(c) Konakova O.Y., 2017

doi:10.15561/18189172.2017.0204
- power trainings with dump bells and rubber strips of different tension positively influenced on indicators of second maturity women's physical fitness [14];

- combination of "Pilates" and aqua-aerobic means with application of special equipment in trainings of 36-55 years' age women permitted to improve their health. It reflected in confident reduction of heart beats rate and blood pressure; in increase dynamometry and respiratory system indicators; in reduction of body mass and circumferences. Besides, physical fitness confidently improved: endurance, flexibility, coordination, strength [16];

- "Pilates" trainings permitted to find positive dynamic of mature women's health $[11,18]$;

- exercises of this system permitted to avoid pains in muscular skeletal apparatus, that influenced on mature people's life quality $[19,25]$.

In other studies positive influence of "Pilates" and "Port de Bras" trainings (Port de Bras is a term from choreography and means "movement of arm and body") on some physical fitness indicators was determined [8]. However, we did not find any works devoted to combining of "Pilates" and "Port de Bras" and their influence on functional state of second maturity women. So our researches will permit to assess effectiveness of such kind of fitness.

The purpose of the research is to find influence of physical culture innovative means (combination of "Pilates" - exercises for body and mind - and program "Port de bras" (movements of arms and body)) on functional state of second maturity women.

\section{Material and methods}

Participants: 22 women of age from 50 to 55 were tested; they were divided into main and control groups.

Organization of the research: control group practiced health related swimming during all periods (10 minutes warming up; general exercises in gym; 40 minutes - main 
part: swimming by "breast stroke" style at moderate and slow temp; final part - swimming at slow temp).

Main group was trained by "Pilates" system. In preparatory period they used exercises on floor (Pilates Mat Work - complexes of exercises to be fulfilled on gymnastic mat in lying or sitting position. Such exercises are targeted at different aims: stimulation of cardiovascular system, improvement of oxygen metabolism, improvement of joints' mobility. In main period: 20\% - practiced exercises on floor and $80 \%$ - used special equipment (rubber strips, gymnastic sticks, fit balls and functional loops). Program "Port de Bras" was applied in warming up and dancing-choreographic components. All trainings were pointed at cardio vascular system's training, development of muscular strength, posture correction, improvement of joints' mobility. The researches were conducted on the base of dance studio of social dances.

Cardio-vascular functional state was determined by heart beats rate indicators (in relaxed state per one minute; recreation time after 20 squatting during 30 seconds). Blood pressure was registered by Korotkov's method with medical tonometer [2].

On the base of women's physical condition indicators we offered health related trainings, based on "Pilates" system (with application of special equipment) and "Port de Bras" program. It should be noted that in all women physical fitness (on the base of pedagogic testing) was low or below average. It was the reason of trainings' practicing in zone of low intensity (mean heart beats rate - 90-115 beats per minute).

The program consisted of two periods: preparatory and main. The quantity of trainings in every period - was twice a week, 60 minutes each. The training consisted of three parts: warming up -10 minutes with heart beats rate 80-100 bpm; main part - 35 minutes with HBR - 100-115 bpm,; and final part - 15 minutes (heart beats rate 80-90 beats per minutes). Macro cycle lasted 10 months. Fitness training consisted of the following components: warming up, dancing-choreographic, power training, stretching and recreation. In preparatory period (1 month) and in main (9 months) we used "Port de Bras" and "Pilates" systems.

"Port de Bras" exercises (including choreographic and fitness elements) were practiced in two periods and included: arms' waving, bending, squatting, dancing step. Exercises with complex coordination were not used. The purpose of such loads was cardiovascular system's training, improvement of joints; mobility, coordination training. Distinctive feature of preparatory period was that exercises were used without special equipment. Special attention was paid to mastering main principles of "Pilates" system and self-control.

In main period (by "Port de Bras" program) load was increased at the account of exercises' coordination complexity. "Pilates" exercises were fulfilled with special equipment: rubber strips, gymnastic sticks, fit balls of 55$65 \mathrm{~cm}$ diameter (depending on body height) and functional loops. Special attention was paid to correct technique of exercises with equipment.

Rubber strips were used for training back, torso, arms and legs muscles. Balance was trained with ball and exercises for balance. Exercises with functional loops were directed at strength and flexibility training, (in particular flexibility of backbone). Compulsory condition was alternation of exercises: development $f$ strength and stretching with relaxation.

Final part of any period included "Pilates" exercises, pointed at stretching and relaxation. Special attention as paid to breathing exercises. Exercises were selected so that one should smoothly pass to the next. Besides, the exercises were fulfilled without sharp change of position.

Statistical; analysis: the processing of the received data was fulfilled with standard Microsoft Excel programs. We found Student's t-criterion for statistic verification of differences' confidence between control and experimental groups' indicators.

\section{Results}

As a result we found that heart beats rate indicators in relaxed state were from 60 to 80 beats per minute; blood pressure- $100 / 60-120 / 80$ in both groups. It means that indicators of 50-55 years' age women (see table 1) were within age standard $[2,9,12]$. Indicator of heart beats rate recreation was below average in all women (from 2 to 3 minutes) [2].

Analysis of second mature women's functional state showed that health related trainings positively influenced on cardio vascular system of both groups' tested. However, we did not find any confident changes between main and

Table 1. Functional indicators of the tested at the beginning of experiment

\begin{tabular}{|c|c|c|c|c|c|c|c|}
\hline \multirow[b]{2}{*}{ Description } & \multicolumn{3}{|c|}{ Main group $(n=11)$} & \multicolumn{3}{|c|}{ Control group ( $n=11)$} & \multirow[t]{2}{*}{$\mathbf{p}$} \\
\hline & $\bar{X}$ & $\sigma$ & m & $\bar{X}$ & $\sigma$ & m & \\
\hline HBR in relaxed state (bpm) & 71.82 & 9.07 & 2.73 & 73.66 & 4.81 & 1.44 & $\geq 0.05$ \\
\hline BP syst., (mm merc. col) & 116.64 & 11.22 & 3.38 & 115.03 & 8.99 & 2.71 & $\geq 0.05$ \\
\hline BP diast., (mm merc. col) & 76.91 & 9.28 & 2.80 & 75.90 & 8.74 & 2.62 & $\geq 0.05$ \\
\hline $\begin{array}{l}\text { Recreation time after } 20 \text { squatting dur- } \\
\text { ing } 30 \text { seconds }(\mathrm{min} / \mathrm{sec})\end{array}$ & -2.50 & 0.98 & 0.29 & 2.58 & 2.06 & 0.62 & $\geq 0.05$ \\
\hline
\end{tabular}

Notes: HBR, bpm - heart beats rate per one minute; BP syst., mm mecr.col. - systolic blood pressure, millimeters of mercury column; BP diast., $\mathrm{mm}$ mecr.col. - diastolic blood pressure, millimeters of mercury column; $\overline{\mathrm{X}}-\mathrm{mean}$ arithmetic value; $\sigma$ - mean square deviation; $m$ - standard error of mean arithmetic. 
Table 2. Functional indicators of the tested after experiment

\begin{tabular}{|c|c|c|c|c|c|c|c|}
\hline \multirow{2}{*}{ Description } & \multicolumn{3}{|c|}{ Main group $(n=11)$} & \multicolumn{3}{|c|}{ Control group $(n=11)$} & \multirow[t]{2}{*}{$\mathbf{p}$} \\
\hline & $\overline{\mathrm{X}}$ & $\sigma$ & m & $\overline{\mathrm{X}}$ & $\sigma$ & m & \\
\hline HBR in relaxed state (bpm) & 71.09 & 9.54 & 2.88 & 72.80 & 4.12 & 1.24 & $\geq 0.05$ \\
\hline BP syst., (mm merc. col) & 114.06 & 10.67 & 3.22 & 114.01 & 9.89 & 2.99 & $\geq 0.05$ \\
\hline BP diast., (mm merc. col) & 76.82 & 10.50 & 3.16 & 75.00 & 10.04 & 3.02 & $\geq 0.05$ \\
\hline $\begin{array}{l}\text { Recreation time after } 20 \text { squatting during } \\
30 \text { seconds ( } \mathrm{min} / \mathrm{sec} \text { ) }\end{array}$ & 2.44 & 0.99 & 1.03 & 2.38 & 3.09 & 0.93 & $\geq 0.05$ \\
\hline
\end{tabular}

Notes: HBR, bpm - heart beats rate per one minute; BP syst., $\mathrm{mm}$ mecr.col. - systolic blood pressure, millimeters of mercury column; BP diast., $\mathrm{mm}$ mecr.col. - diastolic blood pressure, millimeters of mercury column; $\overline{\mathrm{X}}-\mathrm{mean}$ arithmetic value; $\sigma-$ mean square deviation; $m$ - standard error of mean arithmetic.

control groups $(\mathrm{p} \geq 0.05)$. It can be explained by the fact that at the beginning of experiment in all women heart beats rate in relaxed state was within age standard. In such age period it is very important to keep such results.

Besides, substantial factor was also that health related training were conducted in zone of low intensity (mean heart beats value was $90-115$ beats per minute) during all period of health related training. It did not permit to assess confidently the changes in women's functional indicators.

\section{Discussion}

The fulfilled research supplements and proves the data of special literature: with age functional reserves of cardio-vascular system reduce in second mature women $[5,6,9]$. It negatively impacts their health $[3,4]$. So, in this age it is important not to admit reduction of organism's functional potentials, in particular cardio-vascular system of women $[6,9]$.

A number of scientists found "Pilates" system's positive influence on physical fitness of second mature and elderly women: increase of flexibility, strength, power endurance and coordination indicators [23, 26, 27].

The results of our work prove scientific literature data: for confident changes in functional systems of second maturity women it is necessary to conduct trainings in zone of sub-maximal loads $(75-85 \%$ from maximal oxygen consumption); trainings in zone of low intensity do not result in confident health related effect $[15,16,18]$.

Thus we may conclude that in our work we developed the data, concerning functional state of second maturity women $[1,15,16]$.

For the first time, we used combination of aerobic and power oriented program "Port de Bras" and "Pilates" system (with application of equipment) at health related trainings of second maturity women. Besides, it as found that combination of such health related programs positively influenced on functional state of 50-55 years' age women.

\section{Conclusions}

Application of physical culture innovative means ("Pilates" system and "Port de Bras" program) with special equipment) positively influenced on second maturity women's functional state. With low and below average physical fitness level of these women it is necessary to conduct health related trainings in zone of low intensity (mean heart beats value - 90-115 beats per minute) for increasing training intensity it is necessary to raise women's physical fitness level.

\section{Acknowledgements}

The work has been fulfilled within the frames of applied scientific research 2016-2017 "Development and realization of innovative technologies in physical education of different population strata" (state registration number 0116U003476).

\section{Conflict of interests}

The author declares that there is no conflict of interests.

\section{References}

1. Andreeva MV. Osobennosti funkcional'nogo sostoianiia vneshnego dykhaniia $i$ krovoobrashcheniia $u$ zhenshchin 36-55 let pod vliianiem fizicheskoj nagruzki ozdorovitel'noj napravlennosti. Kand. Diss. [Special aspects of external breathing functional state and blood circulation in 36-55 years' age women under influence of health related physical load. Cand. Diss.], Chelyabinsk; 2011. (in Russian)

2. Apanasenko GL. Evoliuciia bioenergetiki i zdorov'ia cheloveka [Evolution of human bio-energetic nad health], Sankt Petersburg: Petropolis; 1992. (in Russian)

3. Bashkin I, Makarova E, Riziq A, Hoosen K. Rol' i misce fizichnoi reabilitacii u zagal'nij sistemi okhoroni zdorov'ia naselennia [Role and place of physical rehabilitation in general system of population's health protection]. Teoriia $i$ metodika fizichnogo vikhovannia i sportu, 2006;3:25-29. (in Ukrainian)

4. Bodyukov EV. Soderzhanie i metodika zaniatij atleticheskoj gimnastikoj ozdorovitel'noj napravlennosti s zhenshchinami 39-49 let. Kand. Diss. [Content and methodic of health related athletic gymnastic training of 39-49 years' age women. Cand. Diss.], Barnaul; 2003. (in Russian)

5. Krucevich TYu, Bezverkhnia GV. Rekreaciia u fizichnij kul'turi riznikh grup naselennia [Recreation in physical culture of different population groups], Kiev: Olympic Literature; 2010. (in Ukrainian)

6. Krucevich TYu. Teoriia i metodika fizicheskogo vospitaniia [Theory and methodic of physical education], Kiev: Olympic 
Literature; 2008. (in Russian)

7. Lyadska OYu. Zagal'ni osnovi sistemi «pilates» $i$ fitnesprogrami «por de bra» [General principles of "Pilates" system and "Port de Bras" program]. Dnipropetrovsk: PF Standard-Service; 2014. (in Ukrainian)

8. Lyadska OYu. Efektivnist' zastosuvannia special'nogo ustatkuvannia na zaniattiakh za sistemoiu «pilates» ta programi «por de bra» z zhinkami drugogo zrilogo viku [Effectiveness of special equipment's application in "Pilates" and "Port de Bras" trainings with second maturity women]. Sportivnij visnik Pridniprov'ia, 2015;2:109 $\quad$-112. (in Ukrainian)

9. Makarova GA. Sportivnaia medicina [Sport medicine], Moscow: Soviet sport; 2006. (in Russian)

10.Pristupa E, Rzepka A, Wojciech L. Rekreaciia iak social'nokul'turne iavishche, riznovid i rezul'tat diial'nosti [Recreation as a social-cultural phenomenon, kind and result of activity]. Sportivna nauka Ukraini, 2008;3:8-20. (in Ukrainian)

11.Robinson L, Thomson G. Pilates: put' vpered ["Pilates" - a way forward]. Minsk: Medley; 2008. (in Russian)

12.Savchenko VG, Moskalenko NV, Lukovskaya OL, Kovtun AA. Sovremennye metody issledovaniia funkcional'nogo sostoianiia serdechno-sosudistoj $i$ dykhatel'noj sistem $v$ fizicheskoj kul'ture $i$ sporte [Modern methods of study of cardio-vascular and respiratory systems' functional state in physical culture and sports], Dnipropetrovsk: Innovation; 2007. (in Russian)

13.Savin SV. Pedagogicheskoe proektirovanie zaniatij fitnesom $s$ zhenshchinami zrelogo vozrasta. Kand. Diss. [Pedagogic projecting of aged women's fitness trainings. Cand. Diss.], Moscow; 2008. (in Russian)

14.Sapozhnikov OV. Ozdorovitel'naia tekhnologiia primeneniia fizicheskikh uprazhnenij s otiagoshcheniiami dlia zhenshchin vtorogo zrelogo vozrasta. Kand. Diss. [Health related technology of physical exercises with weights application for second maturity women. Cand. Diss.], Sankt Petersburg; 2010. (in Russian)

15.Skidan AA, Wroblewski EP. Dinamika morfofunkcional'nogo sostoianiia zhenshchin zrelogo vozrasta $\mathrm{v}$ processe zaniatij shejpingom [Dynamic of aged women's morphological functional state in the process of shaping trainings]. Zhurnal Izvestiia Tul'skogo gosudarstvennogo universiteta, 2014;2:73-79. (in Russian)

16.Fedorova ON. Kompleksnoe primenenie sredstv pilatesa $i$ akvaaerobiki na zaniatiiakh $s$ zhenshchinami vtorogo perioda zrelogo vozrasta. Kand. Diss. [Complex application of "Pilates" and aqua-aerobic means at trainings of second maturity women. Cand. Diss.], Sankt Petersburg; 2012. (in Russian)

17.Arziutov G, Iermakov S, Bartik P, Nosko M, Cynarski WJ. The use of didactic laws in the teaching of the physical elements involved in judo techniques. Ido Movement for Culture, 2016;16(4):21-30. doi:10.14589/ido.16.4.4

18.Bishop JG. Fitness through aerobics-seventh edition. New York; 2006.

19.Vieira ND, Ruas PC, Salvini TF, Catai AM, Melo RC. The effects of 12 weeks Pilates-inspired exercise training on functional performance in older women: A randomized clinical trial. Journal of Bodywork and Movement Therapies. [Internet], 2016 [cited 2016 Jun 21]; Available from: http:// www.bodyworkmovementtherapies.com/article/S1360$8592 \% 2816 \% 2930102-4 /$ fulltext

20.Hoeger WW, Hoeger A. Lifetime Physical Fitness and Wellness: A. Personalized Program. 9 th ed. Belmont, GA. Thompson Wadsworth; 2007.

21.Iermakov SS, Podrigalo LV, Jagiello W. Hand-grip strength as an indicator for predicting the success in martial arts athletes. Archives of Budo. 2016;12:179-86.

22.Khudolii OM, Ivashchenko OV, Iermakov SS, Rumba OG. Computer simulation of Junior gymnasts' training process. Science of Gymnastics Journal, 2016;8(3):215-228.

23.Laís C, Raphael G, Deise A. Comparison between static stretching and the Pilates method on the flexibility of older women. Journal of Bodywork and Movement Therapies, 2016;20(4):800-806.

24.Mazzarino M, Kerr D, Wajswelner H, Morris M. Pilates Method for Women's Health: Systematic Review of Randomized Controlled Trials. Journal of Physical Medicine and Rehabilitation, 2015;96(12):2231-2242.

25. Posadzki P, Lizis P, Hanger-Derengowska M. Pilates for low back pain: a systematic review. Complement Ther Clin Pract. 2011;17:85-89.

26. Yanan Z. A canonical correlation analysis on the relationship between functional fitness and health-related quality of life in older adults. Archives of Gerontology and Geriatrics, 2016;68:44-48.

27.Cruz-Ferreira F, Fernandes J, Bernardo L, Silva A. A Systematic Review of the Effects of Pilates Method of Exercise in Healthy People. Journal of Physical Medicine and Rehabilitation, 2011;92(12):2071-2081.

Information about the author:

Konakova O.Y;; http://orcid.org/0000-0003-1786-3147; ladc@ukr.net; Dnipropetrovsk State Institute of Physical Culture and Sport; Str. Donetsk Highway 2, 123, Dnepropetrovsk, 49080, Ukraine.

Cite this article as: Konakova OY. Influence of physical culture innovative means on functional state of second maturity women. Pedagogics, psychology, medical-biological problems of physical training and sports, 2017;2:71-74. doi:10.15561/18189172.2017.0204

The electronic version of this article is the complete one and can be found online at: http://www.sportpedagogy.org.ua/index.php/PPS/issue/archive

This is an Open Access article distributed under the terms of the Creative Commons Attribution License, which permits unrestricted use, distribution, and reproduction in any medium, provided the original work is properly cited (http://creativecommons.org/licenses/by/4.0/deed.en).

Received: 11.12.2016

Accepted: 10.01.2017; Published: 30.04.2017 